\title{
Net melon resistance to Didymella bryoniae according to grafting and potassium levels
}

\author{
Edvar de Sousa da Silva ${ }^{1}$; Felipe Campaner Palangana ${ }^{1}$; Rumy Goto ${ }^{1}$; Edson Luiz Furtado ${ }^{1}$; Dirceu Maximino \\ Fernandes ${ }^{1}$
}

${ }^{1}$ UNESP/Faculdade de Ciências Agronômicas/Depto. Produção Vegetal, Rua José Barbosa de Barros, 1780, C. postal 237, 18610-307, BotucatuSP, Brasil.

Autor para correspondência: Edvar de Sousa da Silva (edvardesousa@yahoo.com.br)

Data de chegada: 02/08/2011. Aceito para publicação em: 13/02/2012.

\section{ABSTRACT}

Silva, E.S.; Palangana, F.C.; Goto, R.; Furtado, E.L.; Fernandes, D.M. Net melon resistance to Didymella bryoniae according to grafting and potassium levels. Summa Phytopathologica, v.38, n.2, p.139-143, 2012.

Chemical control of the fungus Didymella bryoniae, the causal agent of the disease gummy stem blight in melon, is frequently inefficient; thus, alternatives such as grafting and nutrition must be studied. Rootstocks and potassium levels were tested aimed at controlling this disease in net melon under protected environment. The melon hybrid 'Bônus II', ungrafted and grafted onto 'Dinero' melon and 'Strong Tosa' pumpkin rootstocks, was cultivated and inoculated by using the toothpick insertion method with 7-mm mycelial disks from the isolate D. bryoniae Dbr 37; for control, only toothpick insertion was used. The plants were subjected to the following potassium levels: $0,62.5,125,187.5,250 \mathrm{mg} \mathrm{L}^{-1}$. Grafted 'Bônus II' melon plants were resistant to the fungus, whereas ungrafted ones were susceptible. The adopted potassium levels did not influence the stem lesion size or the survival of plants.

Additional keywords: Cucumis melo var. reticulatus Naud., gummy stem blight, nutrition, rootstock.

\section{RESUMO}

Silva, E.S.; Palangana, F.C.; Goto, R.; Furtado, E.L.; Fernandes, D.M. Resistência de meloeiro rendilhado à Didymella bryoniae em função da enxertia e concentrações de potássio. Summa Phytopathologica, v.38, n.2, p.139-143, 2012.

O controle químico do fungo Didymella bryoniae, agente causal da doença crestamento gomoso em meloeiro, frequentemente é ineficiente, e alternativas como enxertia e nutrição devem ser estudadas. Portaenxertos e concentrações de potássio foram testadas objetivando controlar a doença esta doença em meloeiro rendilhado, sob ambiente protegido. O híbrido de meloeiro 'Bônus II' pé-franco e enxertado em porta-enxertos melão 'Dinero' e abóbora 'Strong Tosa' foram cultivados e inoculados pelo método de inserção de palito com discos de micélio de $7 \mathrm{~mm}$ do isolado de D. bryoniae Dbr 37, e o controle somente com inserção do palito. As plantas foram submetidas às concentrações de potássio $0 ; 62,5 ; 125 ; 187,5 ; 250 \mathrm{mg} \mathrm{L}^{-1}$. Plantas de meloeiro 'Bônus II' enxertadas foram resistentes ao fungo e as não enxertadas suscetíveis. As concentrações de potássio não influenciaram tanto no tamanho da lesão no caule quanto na sobrevivência das plantas.

Palavras-chave adicionais: Cucumis melo var. reticulatus Naud., crestamento gomoso, nutrição, porta-enxerto.

One of the most important diseases affecting net melon (Cucumis melo var. reticulates Naud.) in protected environment is gummy stem blight or stem canker, which is caused by the fungus Didymella bryoniae (12). Chemical control has frequently shown low efficiency; however, some alternatives have been successful, such as grafting onto rootstocks of resistant melons, disinfection of pruning shears, establishment of the protected environment in places other than lowlands, crop rotation, and rational irrigation control $(2,10,12$ and $15)$.

The use of grafting for vegetables such as pepper, tomato, eggplant, cucumber and melon cultures has allowed the solution of problems related to soil pathogens. According to Trionfetti-Nisini et al. (12) and Crino et al. (3), this technique can be an alternative to control the fungus $D$. bryoniae, which is not considered a soil plant but can survive in plant debris in the soil. This alternative was also proven by Ito et al. (4), who tested several rootstocks and concluded that Benincasa hispida was highly resistant to D. bryoniae and most recommended as rootstock for net melon.

Another alternative to control diseases in plants has been mineral nutrition preparation; however, the interaction between nutrition and diseases has been scarcely studied, frequently yielding contradictory results or misinterpretations. On the other hand, the importance of nutrition on the manifestation or not of diseases is well known (13). The effect of nutrition on the intensity of diseases is known for a certain number of plants cultivated under controlled condition, but there are few studies related to the melon culture, especially the net type.

This study aimed to assess net melon resistance to D. bryoniae according to grafting and potassium levels. 


\section{MATERIALAND METHODS}

The experiment was carried out at the Experimental Farm of Teaching, Research and Production belonging to the School of Agronomical Sciences (FCA) of "UNESP-Universidade Estadual

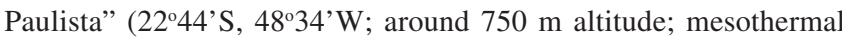
climate type, humid subtropical Cfa). Pots were kept under protected environment, in 10x40m arch-type structure covered with transparent $100 \mu \mathrm{m}$-thick low-density polyethylene (LDPE) film, from May to September 2009

Experimental design was in randomized blocks, in $3 \times 5$ factorial arrangement: 'Bônus II' hybrid melon plants grafted onto 'Dinero' melon and 'Strong Tosa' pumpkin rootstocks, ungrafted 'Bônus II', and five potassium levels: $0,62.5,125,187.5,250 \mathrm{mg} \mathrm{L}^{-1}$, totaling 15 treatments.

The potassium levels $0,62.5,125,187.5$ and $250 \mathrm{mg} \mathrm{L}^{-1}$ represent, respectively, $0 \%, 50 \%$ below the recommended level, the recommended level, $50 \%$ above the recommended level and $100 \%$ above the recommended level according to Kano (5) and were supplied as potassium nitrate.

In each plot, net melon plants (Cucumis melo var. reticulatus Naud.), 'Bônus II' hybrid, grafted and ungrafted, were cultivated in a row spaced at $1.0 \times 0.50 \mathrm{~m}$, totaling 12 plants per plot; six useful plants and two plants at each treatment extreme of a plot served as border.

Before inoculation, D. bryoniae isolates were cultured in PDA (potato dextrose agar) medium autoclaved at $120^{\circ} \mathrm{C}$ for 20 min at 1.5 atm. For each Petri dish containing $20 \mathrm{~mL}$ culture medium, three mycelial disks of $7 \mathrm{~mm}$ diameter were recultured during seven days at $20^{\circ} \mathrm{C}$ in the dark. Inoculation was done at 20 days after transplant by the toothpick method, inserting $7 \mathrm{~mm}$ pathogen mycelial disks into the stem previously injured by a toothpick, adapted from TrionfettiNisini et al. (12). Inoculated plants were kept in a humid chamber for $12 \mathrm{~h}$; they were also sprayed with water and covered with plastic bottles.

Evaluations started at seven days after the inoculation of isolates and continued at every seven days from then. The symptoms were quantified by measuring the longitudinal and the transversal length of necrosis resulting from pathogen colonization. The disease intensity in each plant was the result of the simple arithmetic mean between the two dimensions, constituting the mean diameter of the lesion.

Data were subjected to factorial analysis of variance (F test) at $5 \%$ probability, and Tukey's test at $5 \%$ probability was used to compare means.

\section{RESULTS AND DISCUSSION}

During the experimental period, the maximum temperature ranged from 17.7 to $43.9^{\circ} \mathrm{C}$ and the minimum temperature from 4.5 to 18.3 ${ }^{\circ} \mathrm{C}$ (Figure 1).

As regards the lesion mean diameter, only the means of grafted plants were compared (Table 1 and Figure 2) due to the early and high mortality of ungrafted plants. The latter were compared to grafted plants considering the percentage of plant survival (Table 2 and Figure $3)$.

The main effect of the factor plant type was significant in all evaluations and non-significant for potassium levels and interaction between the two factors on the lesion mean diameter (Table 1) and plant survival (Table 2).

'Bônus II' plants grafted onto 'Dinero' melon rootstock had larger lesion mean diameter in all evaluations, greatly differing from plants grafted onto 'Strong Tosa' pumpkin rootstock, reaching $3.79 \mathrm{~cm}$ at 56 DAI (Days after inoculation) (Figure 2).

For all plants in which the rootstock 'Strong Tosa' was used, the lesion almost did not develop, keeping limited to the rootstock region; the largest lesion mean diameter in these plants was 0.70 $\mathrm{cm}$ at 49 DAI (Figure 2). The results obtained here agree with those reported by Trionfetti-Nisini et al. (12), who observed in melon plants cv. Proteo grafted onto Benincasa hispida, Cucumis metuliferus and Cucumis moschata the occurrence of D. bryoniae symptoms, with lesions keeping restricted to rootstocks, not affecting the grafting.

The lesion non-expansion is due to the rootstock resistance to the fungus attack, probably through the synthesis of new carbohydrates, especially callose and cellulose, which are added to the interior of the cell wall. This occurs when the pathogen starts
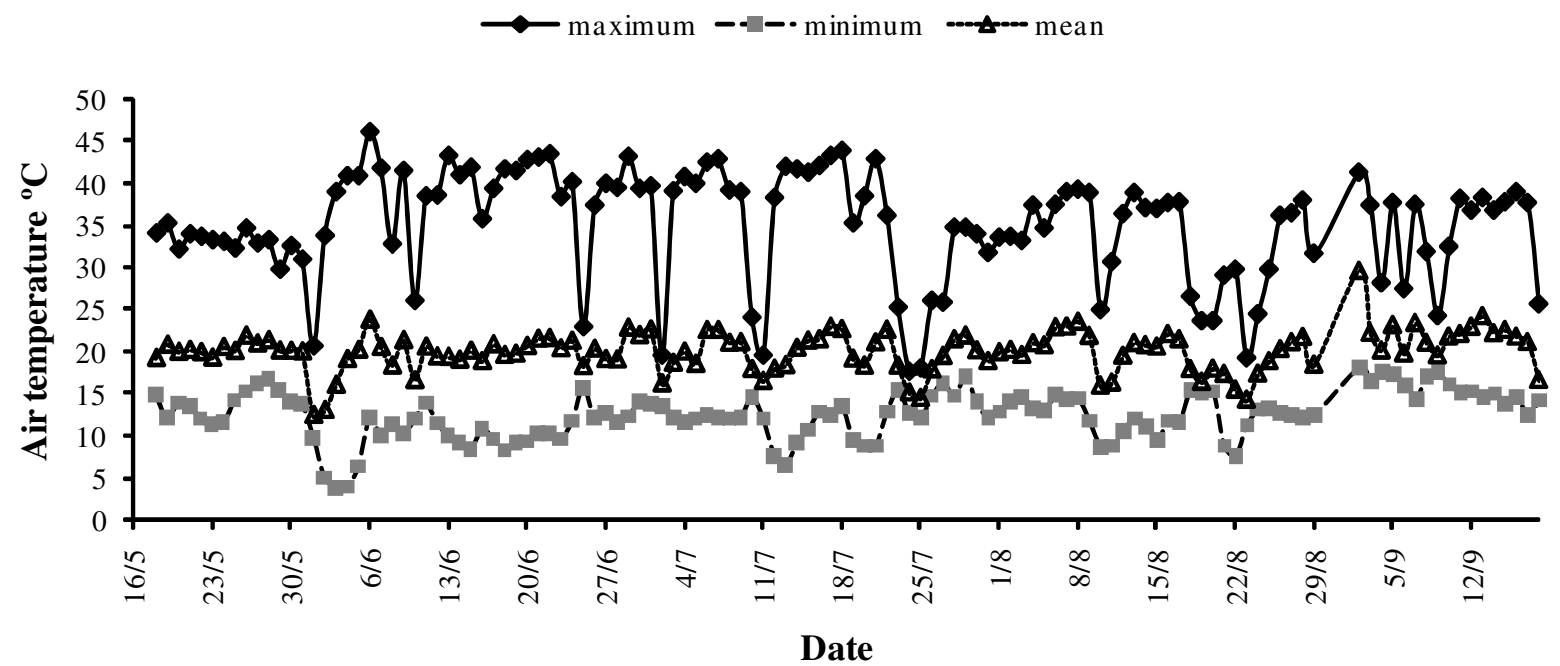

Figure 1. Maximum, minimum and mean temperature in the protected environment from 18/05/2009 to 18/09/2009, São Manuel-SP - FEPP - UNESP/ FCA, Brazil, 2009 


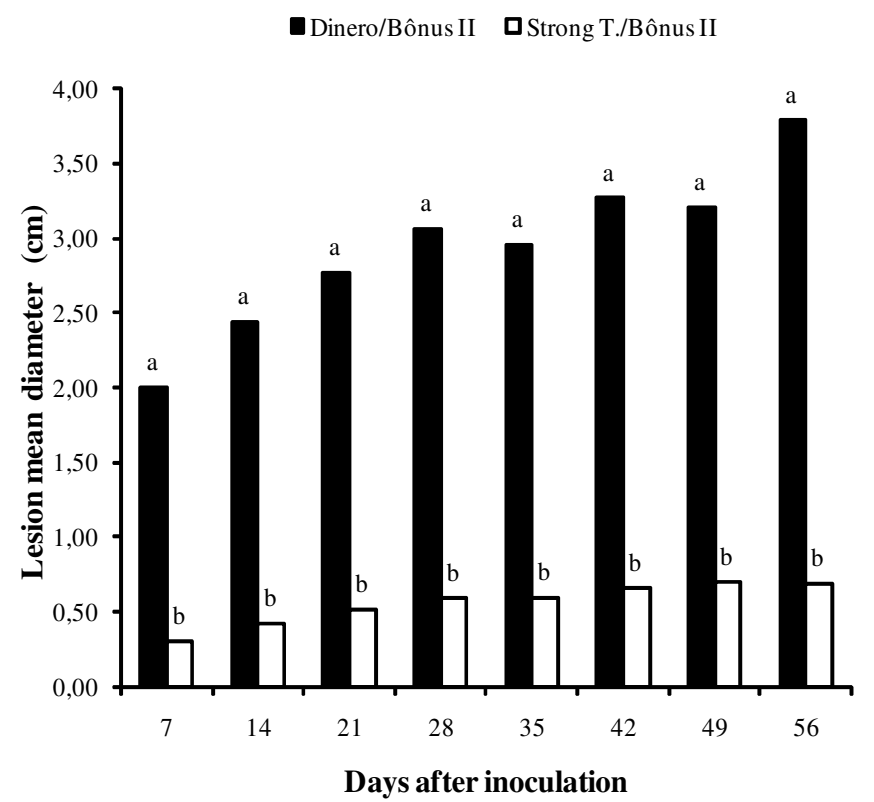

Figure 2. Lesion mean diameter $(\mathrm{cm})$ in the rootstock region of 'Bônus II' plants grafted onto 'Strong Tosa' and 'Dinero' rootstocks. Means followed by the same letter do not differ according to Tukey's test at 5\% probability. São Manuel-SP - FEPP - UNESP/FCA, Brazil, 2009. penetrating the cell wall, using hyphae or infectious haustoria (6). This carbohydrate deposition continues after the pathogen penetration until it becomes configured as a dome or elongated, receiving the name of papilla (1).

The difference between the number of grafted and ungrafted plants surviving during the whole evaluation period was quite clear: at 14 days after inoculation, some 'Bônus II' ungrafted plants were already dead and had the stem cut at the region of the lesion caused by the fungus $D$. bryoniae, and over the experiment almost all plants did not resist and died (Figure 3).

For some plants grafted onto 'Dinero', the lesion developed up to the graft, leading to the death of some of these plants; the latter, however, did not differ statistically from the number of plants grafted onto 'Strong Tosa' rootstock, which was highly resistant and did not lead to plant death (Figure 3).

These results agree with those of Crino et al. (3), who noted that 'Incas' hybrid melon plants grafted onto the commercial rootstocks 'RS 841', '360 P', 'ES 99-13', 'Elsi' were highly resistant both to Fusarium oxysporum f. sp. melonis strains 1 and 2 (100\% survival) and to D. bryoniae, with almost absent lesions and leaves with low disease rate, clearly differing from those grafted onto 'Belimo', 'Energia', 'Griffin', 'ES liscio' and the control 'Incas' in the ungrafted form.

Potassium has been one of the most studied nutrients considering plant resistance to diseases and pests, especially over the last two

Table 1. Summary of the analysis of variance (mean squares and coefficient of variation) for lesion mean diameter according to plant type (TP= grafted plants) and potassium level (K). São Manuel-SP - FEPP - UNESP/FCA, Brazil, 2009.

\begin{tabular}{|c|c|c|c|c|c|c|c|c|c|c|}
\hline Variation & Cause & DF & MS 7 DAI & MS 14 DAI & MS 21 DAI & MS 28 DAÍ & MS 35 DAI & MS 42 DAI & MS 49 DAI & MS 56 DAI \\
\hline $\mathrm{TP}$ & & 1 & $3.32 *$ & $3.18 *$ & $3.00 *$ & $3.02 *$ & $2.73 *$ & $2.80 *$ & $2.57 *$ & $3.09 *$ \\
\hline $\mathrm{K}$ & & 4 & $0.01^{\text {ns }}$ & $0.02^{\mathrm{ns}}$ & $0.02^{\mathrm{ns}}$ & $0.01^{\mathrm{ns}}$ & $0.02^{\mathrm{ns}}$ & $0.01^{\text {ns }}$ & $0.01^{\text {ns }}$ & $0.01^{\mathrm{ns}}$ \\
\hline $\mathrm{TP} \times \mathrm{K}$ & & 4 & $0.02^{\mathrm{ns}}$ & $0.03^{\mathrm{ns}}$ & $0.02^{\mathrm{ns}}$ & $0.01^{\mathrm{ns}}$ & $0.02^{\mathrm{ns}}$ & $0.01^{\mathrm{ns}}$ & $0.03^{\mathrm{ns}}$ & $0.04^{\mathrm{ns}}$ \\
\hline Blocks & & 4 & $0.04 *$ & $0.02^{\mathrm{ns}}$ & $0.01^{\mathrm{ns}}$ & $0.01^{\mathrm{ns}}$ & $0.03^{\mathrm{ns}}$ & $0.02^{\mathrm{ns}}$ & $0.01^{\mathrm{ns}}$ & $0.01^{\mathrm{ns}}$ \\
\hline Total & & 49 & & & & & & & & \\
\hline $\mathrm{CV}(\%)$ & & & 12.82 & 14.12 & 13.86 & 13.96 & 13.95 & 13.83 & 13.07 & 14.12 \\
\hline
\end{tabular}

* Significant at $5 \%$ probability. ${ }^{\mathrm{ns}}$ non-significant at $5 \%$ probability. Original data transformed into $\sqrt{ }(\log (\mathrm{x}+1))$.

Table 2. Summary of the analysis of variance (mean squares and coefficient of variation) for mean number of plants per plot according to plant type (TP= grafted and ungrafted plants) and potassium levels (K). São Manuel-SP - FEPP - UNESP/FCA, Brazil, 2009.

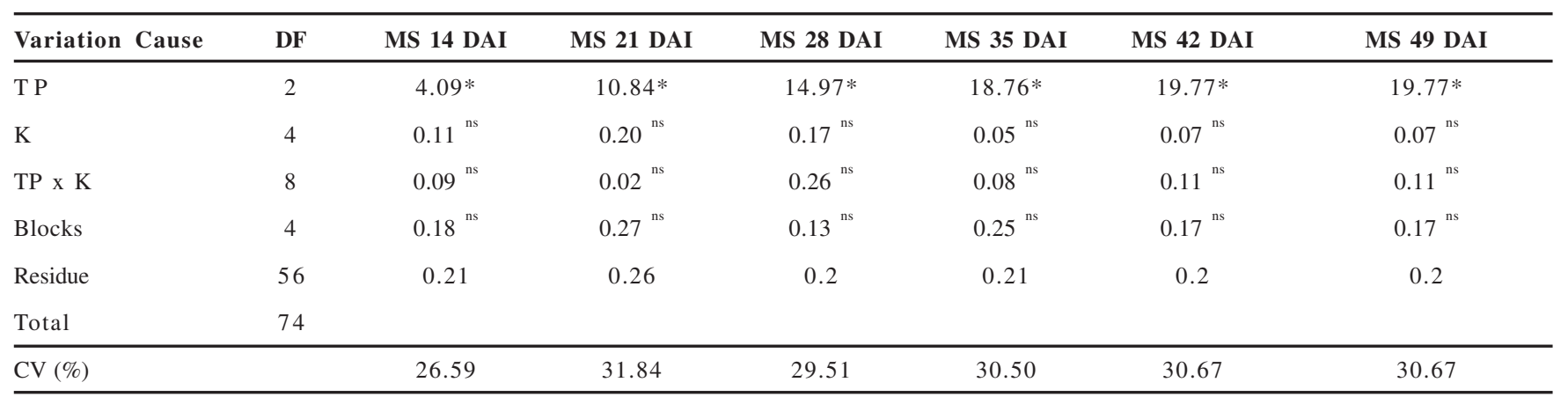

* Significant at $5 \%$ probability. ${ }^{\text {ns }}$ non-significant at $5 \%$ probability. MS: Mean squares. DAI: Days after inoculation 


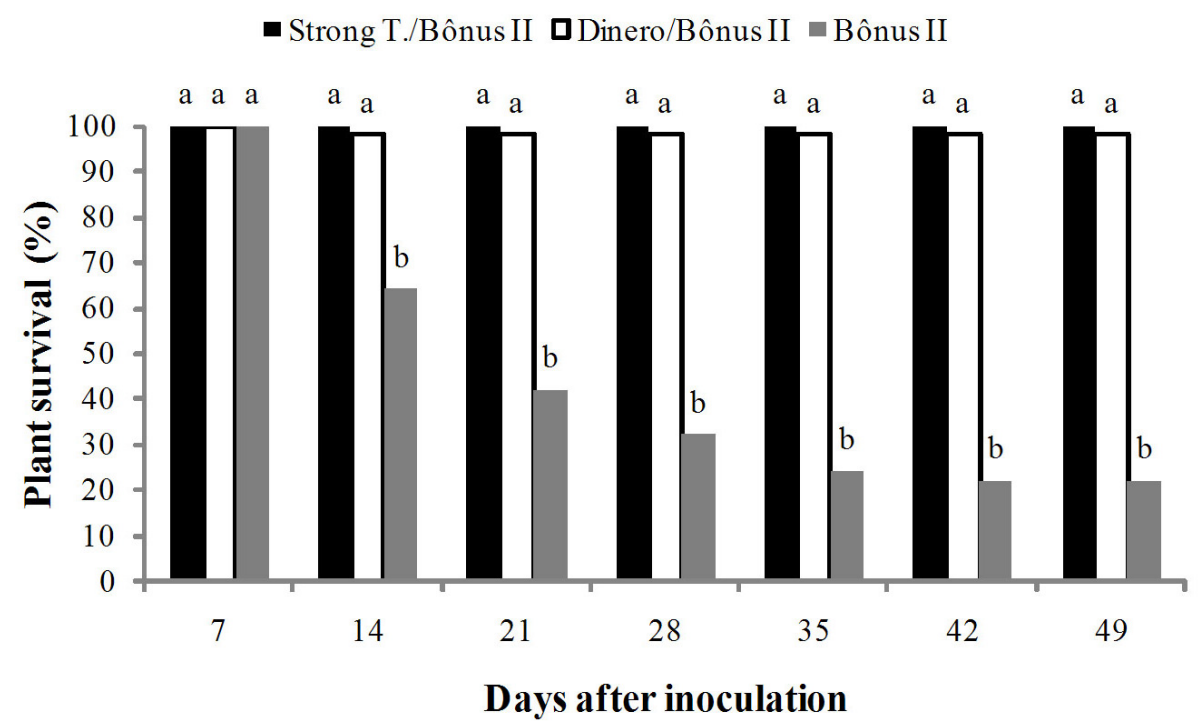

Figure 3. Survival of grafted and ungrafted melon plants (\%) at every seven days after inoculation. Means followed by the same letter did not differ according to Tukey's test at 5\% probability. São Manuel-SP - FEPP - UNESP/FCA, Brazil, 2009.

decades when results were obtained for some diseases or pests affecting certain plants. However, in the present experiments, this nutrient did not influence the lesion mean diameter or the plant survival (Tables 1 and 2), although in the literature there are 2449 reports on the relationship between potassium and plant health considering diseases and pests, with emphasis on fungal diseases $(8,6)$.

The results obtained in this study also agree with those of Santos et al. (10) who evaluated different nitrogen and potassium levels in cover fertilization on stem canker caused by $D$. bryoniae in watermelon; those authors also noted that fertilization did not influence the disease severity, similarly to 15 out of other 200 studies reviewed by Prabhu et al. (9).

Although potassium did not influence the lesion diameter and the severity caused by the fungus $D$. bryoniae, in the literature there is evidence of correlations between the plant nutritional status of $\mathrm{K}$ and the incidence of diseases, but according to Amtmann et al. (2) there is also a clear need of studies related to the effects of $\mathrm{K}$ on physiological, metabolic and hormonal processes, which tend to be essential for the plant susceptibility and sensitivity to pathogenic agents and insects, to better establish these correlations.

$D$. bryoniae is not a soil fungus but can survive for a long time in the soil of places with previous incidence. Thus, grafting has been studied as an alternative to control this fungus both in Brazil and worldwide since chemical control has been inefficient; it may become a tool for producers of melon and the remaining Cucurbitaceae in protected environment, as already used as an alternative to control Fusarium oxysporum f. sp. melonis strains 1 and 2 and some other physiological disturbances that affect this family. The rootstock 'Strong Tosa' was highly resistant to the fungus and can be an alternative control.

\section{ACKNOWLEDGMENTS}

The authors thank the companies Sakata Sudamerica Seed (provider of isolates), Syngenta and Brazil Seeds Takki (provider of rootstocks) and CAPES (financial support).

\section{REFERENCES}

1. Aist, J. R. Papillae and related wound plugs of plant cells. Annual Review of Phytopathology, St. Paul, v. 14, p. 145-163, 1976.

2. Amtmann, A.; Trouffla, S.; Armengaud, P. The effect of potassium nutrition on pest and disease resistance in plants. Physiologia Plantarum, Copenhagen, v. 133, n. 4, p. 682-91, 2008.

3. Crino, P.; Bianco, C.; Rouphael, Y.; Colla, G.; Saccardo, F.; Paratore, A. Evaluation of rootstock resistance to Fusarium wilt and gummy stem blight and effect on yield and quality of a grafted 'Inodorus' melon. HortScience, Alexandria, v. 42, n. 3, p. 521$525,2007$.

4. Ito, L.A.; Braz, L.T.; Castoldi, R.; Charlo, H.C.O.; Camargo, M. Seleção de portas enxertos resistentes ao Cancro da haste e seus efeitos na produtividade de melão 'Bônus 2'. Revista Brasileira de Fruticultura. Jaboticabal, v. 31, n. 1, p. 262-267, mar 2009.

5. Kano, C. Extrações de nutrientes pelo meloeiro rendilhado cultivado em ambiente protegido com a adição de potássio e CO na água de irrigação. 2002. 102 f. Dissertação (Mestrado em² Agronomia) - Escola Superior de Agricultura Luiz de Queiroz, Universidade de São Paulo, Piracicaba, 2002.

6. Malavolta, E. Manual de nutrição mineral de plantas. São Paulo: Agronômica Ceres, 2006. 638 p.

7. Matiello, R. R.; Barbieri, R. L.; Carvalho, F. I. F. Resistência das plantas a moléstias fúngicas. Ciência Rural, Santa Maria, v.27, n.1, p.161-168, 1997.

8. Perrenoud, S.: Potassium and plant health. $2^{\circ}$ ed. rev. Bern: International Potash Institute, 1990. 365 p.

9. Prabhu, A.S.; Fageria, N.K.; Huber, D.M. Potassium nutrition and plant diseases. In: (Eds.) Datnoff, L.E; Elmer, W.H.; Huber, D.M. Mineral nutrition and plant disease. Saint Paul: The American Phytopathological Society Press, 2007. p. 57-78.

10. Santos, G. R.; Café-Filho, A.C.; Saboya, L.M.F. Controle químico do crestamento gomoso do caule na cultura da melancia. Fitopatologia Brasileira, Brasília, v. 30, p.155-163, 2005.

11. Sitterly, W.R. Effect of crop rotation on cucumber gumy stem blight. Plant Disease, Saint Paul, v. 53, p. 417-441, 1969.

12. Trionfetti-Nisini, P.; Buzi, A.; Granati, E.; Chilosi, G.; Crino, P.; Magro, P. Screening for resistance to Didymella bryoniae in rootstocks of melon. OEPP Bulletin, Paris, v. 30, n. 2, p. 231-234, 2000 . 
13. Vida, J.B.; Tessmann, D.J.; Zambolim, L.; Verzignassi, J.R.; Brandão filho, J.U.T. Controle da podridão gomosa em melão rendilhado em cultivo protegido por sanitização de ferramenta de poda. Fitopatologia Brasileira, Brasília, v. 29, p. 626-630, nov-dec. 2004.

14. Walters, D.R.; Bingham, I.J. Influence of nutrition on disease development caused by fungal pathogens: implications for plant disease control. Annals of Applied Biology, Warwick, v. 151, n.3, p.307-324, 2007.

15. Zambolim, L.; Vale, F.X.R.; Costa, H. Controle integrado das doenças de hortaliças. Viçosa: Universidade Federal de Viçosa. 1997. 122p.

16. Zambolim, L.; Costa, H.; Lopes, C.A.; Vale, F.X.R. Doenças de hortaliças em cultivo protegido. In: Zambolim, L.; Vale, F.X.R.; Costa, H. (Eds.) Controle de doenças de plantas-hortaliças. Viçosa. Universidade Federal de Viçosa, v.1, 2000. p.373-407. 